\title{
Relationships between Nutrients and Chlorophyll a Concentration in the International Alma Gol Wetland, Iran
}

\author{
Saeed Bbalali ${ }^{*}$, Seyed Abbas Hoseini², Rasool Ghorbani ${ }^{2}$ and Hamideh Kordi ${ }^{3}$ \\ ${ }^{1}$ Fisheries Department, Gorgan University of Agricultural Sciences and Natural Resources, Iran \\ ${ }^{2}$ Gorgan University of Agricultural Sciences and Natural Resource, Iran
}

${ }^{3}$ National Inland Water Aquaculture Institute, Iran

\begin{abstract}
This study was conducted to find out the Relationships between Nutrients and Chlorophyll a concentration in the International Alma Gol Wetland. Water samples were collected fortnightly from five stations in the wetland. They were collected during summer and autumn. Results illustrated that there was a significant correlation between chlorophyll a and logarithm chlorophyll a with nitrate, nitrite $(P<0.01)$ and ammonia $(P<0.05)$ but there was no significant correlation between chlorophyll a and logarithm chlorophyll a with silica, total alkalinity, sulfate and resolve phosphorus $(\mathrm{P}>0.05)$.
\end{abstract}

Keywords: Nutrients; Chlorophyll a; Alma Gol; Wetland

\section{Introduction}

Wetlands are now recognized as important traits in the landscape that provide numerous useful services for people and fish and wildlife [1]. They are among the most important ecosystems on Earth and considered unique because of their hydrology and their function as ecotones between terrestrial and aquatic ecosystems [2]. These systems are known universal as biodiversity shelters and are among the most biologically various in the world [3].

Chlorophyll a is the major photosynthetic pigment in a lot of phytoplankton and a trophy index in aquatic ecosystems [4,5]. Chlorophyll a ( $\mathrm{Chl} \mathrm{a})$ is often used as an estimate of algal biomass, with blooms being estimated to happen when $\mathrm{Chl}$ a concentrations go above $40 \mu \mathrm{g} \mathrm{L}^{-1}$ [6]. So a methods for the estimation of the growth and development of the phytoplankton community is to perform an analysis of photosynthetic pigments, even though the content of chlorophyll in the cells changes with the availability of light [7] and thus with depth and trophic gradient [8].

Because eutrophication is defined as an aquatic ecosystems response to nutrient loading [9], the ability to identify important factors and predict subsequent algal blooms with the use of a $\mathrm{Chl}$ a equation could be a key lake water management tool. Both chemical and physical controls can be used to prevent or remove algae or algae byproducts from the water [6]. In particular, information about the form of nutrient-Chl relationships [10,11] has allowed lake managers to establish nutrient concentration and loading aims. Nitrogen and phosphorus are often identified limiting nutrients to algal biomass and silicon is necessary for diatom growth [12]. Nitrogen occurs in fresh water in numerous forms: dissolved nitrogen, amino acids, amines, urea, ammonium $\left(\mathrm{NH}_{4}^{+}\right)$, nitrite $\left(\mathrm{NO}_{2}^{-}\right)$, and nitrate $\left(\mathrm{NO}_{3}^{-}\right)$[7]. In aquatic ecosystems, phosphorus $(\mathrm{P})$ can be found either in particulate matter or as soluble inorganic phosphorus, orthophosphate $\left(\mathrm{PO}_{4}^{3-}\right)$ [13].

A review of the 1995 to 1997 biological abstracts about significant factor for algal blooms, illustrates that, of 596 articles on estuaries and nutrients, $52 \%$ consider only nitrogen, $32 \%$ refer to both nitrogen and phosphorus, and $16 \%$ consider only phosphorus, although the preponderance of study on $\mathrm{N}$, the evidence for general $\mathrm{N}$ limitation of coastal systems is feeble compared to the data for general $\mathrm{P}$ limitation of freshwater systems [14].
There have been a small number of comprehensive analyses of the form of phosphorus-chlorophyll relationships. The phosphoruschlorophyll relationship most probably outcomes from the dependence of algal growth rates on phosphorus availability [15]

Nitrogen limitation of algal biomass seems to be more general in subtropical and tropical lakes [16-18], while phosphorus appears to be the primary limiting nutrient in temperate lakes [19]. Other nutrients, for example iron and silicate, have been reported to be limiting in some other regions $[20,21]$. The limiting nutrient is decided mainly by the mass equilibrium between elements such as $\mathrm{C}, \mathrm{N}, \mathrm{P}$, and $\mathrm{Si}$, and their relationship to the growth requirements of the phytoplankton [22].

This research was conducted to determine the relationships between chlorophyll a and nutrients concentrations in the Alma Gol wetland for identify important and effective nutrients on Chl a concentration. Because of $\mathrm{Chl}$ a identified as a major photosynthetic pigment in a lot of phytoplankton and a trophy index in aquatic ecosystems and the other hand the chlorophyll a concentration in the phytoplankton cells changes with nutrients and environmental factors so know about the effective factors on chlorophyll a concentration is very important for ecosystem management.

\section{Materials and Methods}

This study was conducted in Alma Gol international wetland, which is situated on the Turkmen steppes near the border with Turkmenistan in the Golestan Province, in north of Iran (Figure 1). Area of the wetland was 207 ha.

*Corresponding author: Saeed balali, M. Sc. Student, Fisheries Department Gorgan University of Agricultural Sciences and Natural Resource, Iran, Tel: 09112777053, E-mail: saeed_balali85@yahoo.com

Received December 11, 2012; Accepted January 28, 2013; Published February 08, 2013

Citation: Balali S, Hoseini SA, Ghorbani R, Kordi H (2013) Relationships between Nutrients and Chlorophyll a Concentration in the International Alma Gol Wetland, Iran. J Aquac Res Development 4: 173 doi:10.4172/2155-9546.1000173

Copyright: (c) 2013 Balali S, et al. This is an open-access article distributed under the terms of the Creative Commons Attribution License, which permits unrestricted use, distribution, and reproduction in any medium, provided the original author and source are credited. 


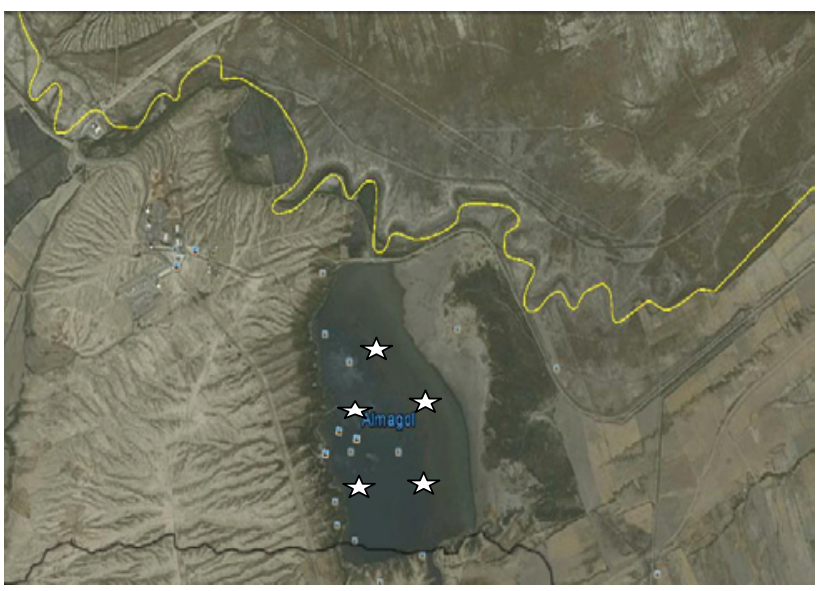

Figure 1: Location of Alma Gol wetland and situation of sampling stations.

\section{Field sampling}

During summer to autumn in 2011, water samples were collected fortnightly from five sampling stations to determine nutrients and chlorophyll-a concentration. Site sampled showed in Figure 1 by white stars. Stations chose with navigate location and regards water depth, macrophyts populations, wind direction, input and output of wetland water. All sampling conducted between 10 to 1 o clocks. The water temperature during sampling was $21.10 \pm 9.59$ centigrade. Usually the weather in summer was sunny and in autumn was rainy and windy. Samples gave from Secchi disk depth by P.V.C. tube. At each sampling station, one liter water collected to determine chlorophyll a and one liter for measured nutrient concentrations. Water samples were lightprotected and transferred to laboratory at $4^{\circ} \mathrm{C}$.

\section{Chlorophyll a determination}

For determination chlorophyll a concentration, samples were shaken and certain volume of water (based on water color) was filtered using a vacuum pomp and GF/F filter. Thereafter, filter was pulverized with $90 \%$ acetone in a mortar. The resulting mixture was centrifuged for $10 \mathrm{~min}$. (3000 rpm) and supernatant was poured into a glass cavetti. The optical density was read at 630, 647, 664 and $750 \mathrm{~nm}$. Chlorophyll a concentrations were calculated according to Jeffrey and Humphrey [23].

\section{Nutrient determination}

In this research we measured ammonia, nitrite, nitrate, silica, sulfate, total alkalinity and resolve phosphorus by especial tablets and photometer set with Wagtech specific recipe and method.

\section{Statistical analyses}

Data were analyzed by statistical software SPSS v. 18 and Microsoft office Excel 2007. Data were subjected by correlate and Bivariate test to find significant relationship between chlorophyll a and nutrient concentration and Duncan's test to find significant difference between nutrients concentration during sampling. $\mathrm{P}<0.05$ considered to be significantly different.

\section{Results}

Results illustrated that there was a negative and significant relationships between chlorophyll a and logarithm chlorophyll a with nitrate, nitrite $(\mathrm{P}<0.01)$ and ammonia $(\mathrm{P}<0.05)$ but there was no significant correlation between chlorophyll a and logarithm chlorophyll a with silica, total alkalinity, sulfate and resolve phosphorus $(\mathrm{P}>0.05)$ (Table 2). Chlorophyll-a ranged between 4.38 to $156.55 \mathrm{mg} / \mathrm{m}^{3}$, sulfate ranged between 138 to $190 \mathrm{mg} / \mathrm{l}$, total alkalinity ranged between 80 to $280 \mathrm{mg} / \mathrm{l}$, silica ranged between 3.80 to $35.00 \mathrm{mg} / \mathrm{l}$, phosphate ranged between 0.02 to $3.70 \mathrm{mg} / \mathrm{l}$, ammonia ranged between 0.10 to $11.90 \mathrm{mg} / \mathrm{l}$ nitrate ranged between 0.01 to $2.75 \mathrm{mg} / \mathrm{l}$ and nitrite ranged between 0.01 to $0.39 \mathrm{mg} / \mathrm{l}$. We illustrated the average of these factors and significant differences between months in table 1.

Regression line for $\log \mathrm{Chl}$ a: $\mathrm{NO}_{2}, \log \mathrm{Chl}$ a: $\mathrm{NO}_{3}, \log \mathrm{Chl}$ a: $\mathrm{NH}_{3}$,

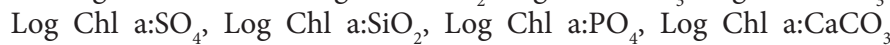
relations was showed in Figure 2 and explained below.

$$
\begin{aligned}
& \mathrm{y}=-0.003 \mathrm{x}+2.118 \quad \mathrm{R}^{2}=0.012, \mathrm{r}=-0.105 \quad \mathrm{Log} \mathrm{Chl} \mathrm{a}: \mathrm{SO}_{4} \\
& \mathrm{y}=-1.888 \mathrm{x}+1.758 \quad \mathrm{R}^{2}=0.161, \mathrm{r}=-0.654 \quad \log \mathrm{Chl} \mathrm{a}: \mathrm{NO}_{2} \\
& \mathrm{y}=0.004 \mathrm{x}+1.482 \quad \mathrm{R}^{2}=0.002, \mathrm{r}=0.124 \quad \log \mathrm{Chl} \mathrm{a:SiO}{ }_{2} \\
& \mathrm{y}=-0.289 \mathrm{x}+1.706 \quad \mathrm{R}^{2}=0.261, \mathrm{r}=-0.701 \quad \log \mathrm{Chl} \mathrm{a}: \mathrm{NO}_{3} \\
& \mathrm{y}=-0.046 \mathrm{x}+1.688 \quad \mathrm{R}^{2}=0.110, \mathrm{r}=-0.457 \quad \log \mathrm{Chl} \mathrm{a}: \mathrm{NH}_{3} \\
& \mathrm{y}=0.017 \mathrm{x}+1.519 \quad \mathrm{R}^{2}=0.000, \mathrm{r}=0.005 \quad \text { Log Chl a: } \mathrm{PO}_{4} \\
& \mathrm{y}=0.001 \mathrm{x}+1.392 \quad \mathrm{R}^{2}=0.014, \mathrm{r}=0.158 \quad \log \mathrm{Chl} \mathrm{a}: \mathrm{CaCO}_{3}
\end{aligned}
$$

\section{Discussion}

The significant correlation between chlorophyll a and nitrite, nitrate and ammonia was found in this research, as the amount of chlorophyll a was high the amounts of nitrite, nitrate and ammonia were in the lowest, but chlorophyll a was not affected by silica, total alkalinity, sulfate and resolve phosphorus.

Power relationships between phosphorus, chlorophyll, and water clarity have been observed for freshwater systems in the world $[24,25]$. The strong relationship between chlorophyll and phosphorus established by Sakamoto [24] in numerous Japanese lakes forms appropriate testable hypothesis: chlorophyll is both a useful and an easy estimator of phytoplankton standing crop and is now more generally used than cell number or cell volume.

Smith [26] achieved the most comprehensive analysis of phosphorus-chlorophyll relationships to date, and was the first to illustrate that information of both TP and TN concentrations could improve predictions of algal biomass. A hypothesis that fits more closely with the classic Liebigian paradigm [27-30] would consider other nutrients that might limit algal growth at high levels of ambient phosphorus. It would predict that chlorophyll should rise linearly until some other quantity (such as nitrogen, silicon, molybdenum and light) becomes limiting. Despite the fact that nonlinear relationships between $\mathrm{TP}$ and chlorophyll between lakes are possible [31,32], there have been little quantitative examinations on their shape or form.

Hoyer et al. [33] suggested that phosphorus accounts for more variance in chlorophyll than in nitrogen in nearshore coastal Florida waters and fresh water. While nitrogen had been shown to limit algal populations in both systems $[34,35]$, the data presented suggested that phosphorus was the primary nutrient limiting algal populations amongst the 300 nearshore coastal locations sampled. They recognized, though, that some of these 300 stations may at some times be limited by nitrogen. Canfield [32] and Brown et al. [25] have formerly affirmed that phosphorus is the primary limiting nutrient in Florida lakes, and when the total nitrogen to total phosphorus ratio moves below 10, nitrogen may become limiting. It is normally assumed, that nitrogen is the primary limiting nutrient for phytoplankton production in most coastal waters [35].

Brown et al. [25] explained that TP alone accounted for a significant 
Citation: Balali S, Hoseini SA, Ghorbani R, Kordi H (2013) Relationships between Nutrients and Chlorophyll a Concentration in the International Alma Gol Wetland, Iran. J Aquac Res Development 4: 173 doi:10.4172/2155-9546.1000173

Page 3 of 5

\begin{tabular}{|l|l|l|l|l|}
\hline Variables & August & September & October & November \\
\hline $\mathrm{NO}_{2}$ & $0.14 \pm 0.1^{\mathrm{ab}}$ & $0.18 \pm 0.1^{\mathrm{a}}$ & $0.08 \pm 0.02^{\mathrm{b}}$ & $0.11 \pm 0.03^{\mathrm{ab}}$ \\
\hline $\mathrm{NO}_{3}$ & $0.60 \pm 0.58^{\mathrm{b}}$ & $1.34 \pm 0.95^{\mathrm{a}}$ & $0.18 \pm 0.03^{\mathrm{b}}$ & $0.47 \pm 0.32^{\mathrm{b}}$ \\
\hline $\mathrm{NH}_{3}$ & $4.72 \pm 3.50^{\mathrm{a}}$ & $4.78 \pm 3.88^{\mathrm{a}}$ & $1.90 \pm 0.69^{\mathrm{a}}$ & $0.06 \pm 0.02^{\mathrm{b}}$ \\
\hline $\mathrm{PO}_{4}$ & $0.50 \pm 1.13^{\mathrm{a}}$ & $0.14 \pm 0.06^{\mathrm{a}}$ & $0.12 \pm 0.09^{\mathrm{a}}$ & $0.33 \pm 0.08^{\mathrm{b}}$ \\
\hline $\mathrm{SiO}_{2}$ & $10.15 \pm 6.28^{\mathrm{a}}$ & $9.67 \pm 1.94^{\mathrm{a}}$ & $9.36 \pm 1.24^{\mathrm{a}}$ & $0.11 \pm 0.07^{\mathrm{a}}$ \\
\hline $\mathrm{CaCO}_{3}$ & $153.00 \pm 67.59^{\mathrm{a}}$ & $88.50 \pm 5.80^{\mathrm{b}}$ & $94.00 \pm 6.52^{\mathrm{b}}$ & $12.27 \pm 8.18^{\mathrm{a}}$ \\
\hline $\mathrm{SO}_{4}$ & $160.30 \pm 16.53^{\mathrm{b}}$ & $184.00 \pm 3.16^{\mathrm{a}}$ & $185.00 \pm 6.12^{\mathrm{a}}$ & $108.50 \pm 13.75^{\mathrm{b}}$ \\
\hline $\mathrm{Chla}$ & $52.46 \pm 20.79^{\mathrm{b}}$ & $23.03 \pm 14.59^{\mathrm{cd}}$ & $136.83 \pm 15.80^{\mathrm{a}}$ & $176.50 \pm 3.37^{\mathrm{a}}$ \\
\hline
\end{tabular}

Different letters show significant difference between columns $(P<0.05)$.

$a$ and $b$ show significant differences between nutrient concentration in different months.

Table 1: Mean \pm SD of nutrients concentration during sampling in Alma Gol wetland.

\begin{tabular}{|l|l|l|l|l|l|l|l|l|}
\hline & $\mathrm{Chla}$ & $\mathrm{Log} \mathrm{Chl} \mathrm{a}$ & $\mathrm{NO}_{2}$ & $\mathrm{NO}_{3}$ & $\mathrm{NH}_{3}$ & $\mathrm{PO}_{4}$ & $\mathrm{SiO}_{2}$ \\
\hline $\mathrm{Chl} \mathrm{a}$ & 1 & & & & & \\
\hline $\mathrm{Log} \mathrm{Chl} \mathrm{a}$ & $0.889^{* *}$ & 1 & 1 & & & \\
\hline $\mathrm{NO}_{2}$ & $-0.486^{* *}$ & $-0.654^{* *}$ & $-0.701^{* *}$ & $0.895^{* *}$ & 1 & & \\
\hline $\mathrm{NO}_{3}$ & $-0.489^{* *}$ & $-0.444^{*}$ & $-0.457^{*}$ & $0.482^{* *}$ & $0.535^{* *}$ & 1 & & \\
\hline $\mathrm{NH}_{3}$ & -0.038 & 0.005 & -0.005 & -0.120 & -0.013 & 1 & \\
\hline $\mathrm{PO}_{4}$ & 0.061 & 0.124 & 0.186 & 0.092 & -0.043 & -0.160 & \\
\hline $\mathrm{SiO}_{2}$ & 0.043 & 0.158 & -0.220 & $-0.365^{*}$ & -0.117 & 0.249 & \\
\hline $\mathrm{CaCO}_{3}$ & 0.055 & -0.105 & 0.227 & 0.283 & 0.027 & $-0.373^{*}$ & 0.159 \\
\hline $\mathrm{SO}_{4}$ & & & & & & \\
\hline
\end{tabular}

${ }^{* *}$ Correlation is significant at the 0.01 level (2-tailed)

${ }^{*}$ Correlation is significant at the 0.05 level (2-tailed).

Table 2: Nutrients and chlorophyll a relationship in Alma Gol wetland.
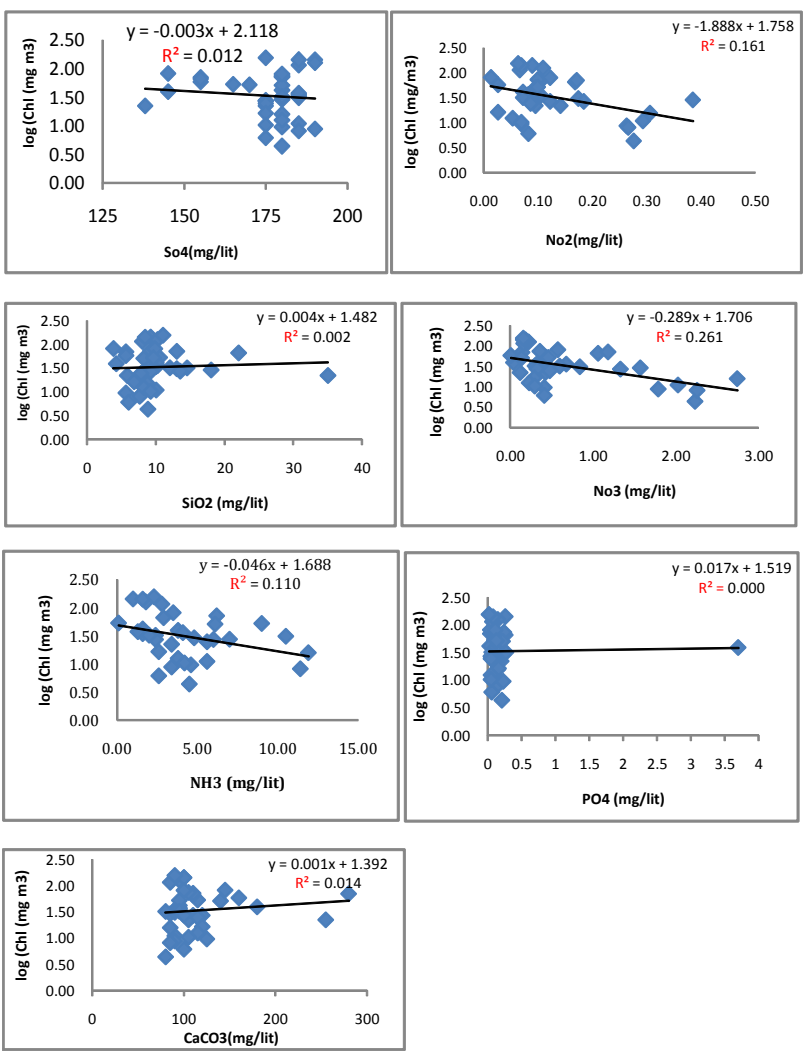

Figure 2: Log Chl a:NO, Log Chl a:NO, Log Chl a:NH $\mathrm{NH}_{3}$ Log Chl a:SO Log Chl a:SiO, Log Chl a:PO, Log Chl a: $\mathrm{CaCO}_{3}$ relations for Alma Gol wetland.

amount of the variance $\left(\mathrm{R}_{2}=0.76\right)$ of observed $\mathrm{Chl}$ measurements and $\mathrm{TN}$ alone accounted for less variance of observed $\mathrm{Chl}$ measurements
$\left(\mathrm{R}_{2}=0.46\right)$, but a multivariate model using both $\mathrm{TP}$ and $\mathrm{TN}$ also accounted for a significant amount of the observed variance $\left(\mathrm{R}_{2}=0.78\right)$. The coefficient of determination values for TP-Chl and the multivariate nutrient-Chl, were similar $\left(\mathrm{R}_{2}=0.76\right.$ against 0.78$)$, suggesting that $\mathrm{Chl}$ concentrations can be predicted rationally well using TP alone. The coefficient of determination for the relationship between TP and Chl for both equations was positive and significant.

Redfield [36] expressed that phosphorus (P) has been considered a key limiting nutrient in marine systems. Furthermore, $\mathrm{P}$ controls of phytoplankton biomass in numerous freshwater systems and similarities in phytoplankton physiology and nutrient requirements in coastal and freshwater systems [12] make P control of coastal systems naturally appealing. Nevertheless, following Ryther and Dunstan's [37] influential work, nitrogen $(\mathrm{N})$ is generally seen as the limiting nutrient in coastal systems and has received the bulk of research interest. Meeuwig et al. [14] illustrated that the relation between Chl and TN is marginally stronger than that between $\mathrm{Chl}$ and $\mathrm{TP}$ suggests that $\mathrm{TN}$, rather than TP, limits estuarine Chl. The average TN: TP ratio of 4.5 also supports the argument for $\mathrm{TN}$ as the key limiting nutrient in estuaries in Prince Edward Island in Canada. However, the relative strength of these patterns and, the TN: TP ratio cannot be used to conclude which nutrient is limiting phytoplankton biomass, the low yield of Chl per unit nutrient points to the importance of other factors such as herbivory and turbidity, and potentially to indirect control by iron, in determining phytoplankton biomass.

Canfield [32] developed a Chl a equation using samples from 223 Florida lakes, $27 \%$ of which were considered N-limited. Because of the long growing season in Florida, these samples were taken during August 1979 to September 1980. Chl a showed significant correlations with both TP $(\mathrm{r}=0.79, \mathrm{p}<0.01)$ and total $\mathrm{N}(\mathrm{TN})(\mathrm{r}=0.87, \mathrm{p}<0.01)$.

The TN relationship was obvious when plotting Chl a concentrations versus TP. Total P concentrations over $100 \mu \mathrm{g} \mathrm{L}^{-1}$, which for most lakes 
Citation: Balali S, Hoseini SA, Ghorbani R, Kordi H (2013) Relationships between Nutrients and Chlorophyll a Concentration in the International Alma Gol Wetland, Iran. J Aquac Res Development 4: 173 doi:10.4172/2155-9546.1000173

yielded TN/TP ratios fewer than 10, produced a gradient change of the TP/Chl a linear relationship. This suggested that $\mathrm{P}$ is the limiting nutrient lower TP levels of $100 \mu \mathrm{g} \mathrm{L}^{-1}$, and that $\mathrm{N}$ is the limiting nutrient higher than that concentration. Researchers have shown that there is often a strong correlation between total phosphorus (TP) and algal biomass $[10,24,38,39]$. This suggests that $\mathrm{P}$ may be the element controlling algal growth. Though, lakes surrounded by rich phosphate deposits and P-containing soils may be N-limited.

$\mathrm{Wu}$ and Chou [22] indicated that both the concentration of chlorophyll a and phytoplankton biomass have shorter Euclidean distances to silicate, nitrate, biochemical oxygen demand, and temperature, than to phosphate, nitrite, ammonium, or physical factors such as conductivity, $\mathrm{pH}$, and dissolved oxygen, suggesting that phytoplankton are associated with silicate, nitrate, biochemical oxygen demand and temperature. These results supported the hypothesis that nutrients such as silicate and nitrate play a more important role in regulating phytoplankton in subtropical eutrophic estuary of Taiwan than do other factors.

In conclusion, results illustrated that there was a negative and significant relationships between chlorophyll a and logarithm chlorophyll a with nitrate, nitrite $(\mathrm{P}<0.01)$ and ammonia $(\mathrm{P}<0.05)$ but there was no significant correlation between chlorophyll a and logarithm chlorophyll a with silica, total alkalinity, sulfate and resolve phosphorus $(\mathrm{P}>0.05)$ in this research. Some research supported the result of this study and some of them were against. Although we could not find any relationship between $\mathrm{Chl}$ a and $\mathrm{P}$ it can be, because of measured resolve phosphorus instead of total phosphorus.

\section{Acknowledgements}

Thanks to A. Jafar node, critic of Shahid Naser Fazli barabadi Aquaculture Research Station for helpful and constructive comments. This research was supported from grants from the Department of Fisheries, Faculty of Fisheries and Environment, Gorgan University of Agricultural Sciences and Natural Resources

\section{References}

1. Environmental Protection Agency (EPA) (2001) Functions and Values of Wetlands. Agency of Oceans and Watersheds, United States Office of Water, 843-F-01-002c.

2. Mitsch WJ, Gosselink JG (2007) Wetlands. John Wiley \& Sons, Inc., Estados Unidos.

3. Junk WJ, Brown M, Campbell IC, Finlayson M, Gopal B, et al. (2006) The comparative biodiversity of seven globally important wetlands: a synthesis. Aquat Sci 68: 400-414

4. Vollenweider RA (1969) Möglichkeiten und Grenzen elementarer Modelle der Stoffbilanz von Seen. Archiv fuÉr Hydrologie 66: 1-36.

5. Dillon PJ (1975) The phosphorus budget of Cameron Lake. Ontario: The importance of flushing rate to the degree of eutrophy of lake. Limnol Oceanogr 20: $28-29$.

6. Stanley CD, Clarke RA, McNeal BL, MacLeod BW (2003) Relationship of Chlorophyll a Concentration to Seasonal Water Quality in Lake Manatee, Florida. In: Publication of the Soil and Water Science Department, Florida Cooperative Extension Service, IFAS, University of Florida, EDIS.

7. Wetzel RG (2001) Limnology Lakes and Rivers ecosystems, San Diego Academic press, USA.

8. Kasprzak P, Padisak J, koschel R, Krienitz R, Gervais R, et al. (2008) Chlorophyll a concentration across a trophic gradient of lakes: An estimator of phytoplankton biomass?. Limnologica 38: 327-338.

9. Edmondson WT (1991) The uses of ecology: Lake Washington and beyond Univ of Washington Press, Seattle Environment Canada (1990) Activities affecting surface water resources a general overview. The Canada-PE1 Water Management Agreement Ministry of Supply and Services, Otlawa.
10. Dillon PJ, Rigler FH (1974) The phosphorus-chlorophyll relationships in lakes. Limnol Oceanogr 19: 767-773.

11. Prairie YT, Duarte CM, Kalff J (1989) Unifying nutrient-chlorophyll relationships in lakes. Can J Fish Aquat Sci 46: 1176-1182.

12. Hecky RE, Kilham P (1988) Nutrient Limitation of Phytoplankton in Freshwate and Marine Environments: A Review of Recent Evidence on the Effects of Enrichment. Limnol Oceanogr 33: 796-822.

13. Knud-Hansen C (1997) Experimental design and analysis in aquaculture. In: Egan HS, Boyd CE (eds.). Dynamics of pond aquaculture CRS Press Boca/ Raton New York: 325-375.

14. Meeuwig JJ, Rasmussen JB, Peters RH (1998) Turbid waters and clarifying mussels: their moderation of empirical chknutrient relations in estuaries in Prince Edward Island, Canada. Mar Ecol Prog Ser 171: 139-150.

15. McCauley E, Downing JA, Watson S (1989) Sigmoid relationships between nutrients and chlorophyll among lakes. Can J Fish Aquat Sci 46:1171-1175.

16. Henry R, Hino K, Tundisi JG, Ribeiro JSB (1985) Responses of phytoplankton in Lake Jacaretinga to enrichment with nitrogen and phosphorus in concentrations similar to those of the River Solimoes (Amazon, Brazil). Arch Hydrobiol 103 453-477.

17. Davalos L, Land OT, Dole RD (1989) Evaluation of phytoplankton limiting factors in Lake Capella, Mexico: turbidity and the spatial and temporal variation in algal assay response. Lake Reservoir Manage 5: 99-104.

18. Hecky RE, Campbell P, Handsale LL (1993) The stoichiometry of carbon nitrogen, and phosphorus in particulate matter of lakes and oceans. Limno Oceanogr 38: 709-724.

19. Smith VH (1990) Phytoplankton responses to eutrophication in inland waters. In: Akatsuka I, Junk W (eds.). Introduction to applied phycology. The Hague, The Netherlands: 231-249.

20. Johnson KS, Chavez FP, Friederich GE (1999) Continental-shelf sediment as a primary source of iron for coastal phytoplankton. Nature 398: 697-700.

21. Yolanda DA, Olivier LP, Paul T, Bernard Q, Alain M, et al. (1997) Impacts of high-nitrate freshwater inputs on macrotidal ecosystem: I. Seasonal evolution of nutrient limitation for the diatom-dominated phytoplankton of the Bay of Brest (France). Mar Ecol Prog Ser 161: 213-224.

22. Wu JT, Chou TL (2003) Silicate as the limiting nutrient for phytoplankton in subtropical eutrophic estuary of Taiwan. Estuarine. Coastal and Shelf Science 58: 155-162.

23. Jeffrey SW, Humphrey GF (1975) New spectrophotometric equations for determining chlorophylls $\mathrm{a}, \mathrm{b}, \mathrm{c} 1$ and $\mathrm{c} 2$ in higher plants, algae and natura phytoplankton. Biochem Physiol 167: 191-194.

24. Sakamoto M (1966) Primary production by phytoplankton community in some Japanese lakes and its dependence on lake depth. Hydrobiologia 62: 1-28.

25. Brown CD, Hoyer MV, Bachmann RW, Canfield DE (2000) Nutrient- Florida and northern temperate lake data. Can J Fish Aquat Sci. 57: 1574-1583.

26. Smith VH (1982) The nitrogen and phosphorus dependence of algal biomass in lakes: an empirical and theoretical analysis. Limnol Oceanogr 27:1101- 1112

27. Von Liebig J (1840) Chemistry and its application to agriculture and physicology Taylor and Walton, London.

28. Hutchinson GE (1973) Eutrophication. Am Sci 61: 269-279.

29. Droop MR (1974) The nutrient status of algal cells in continuous culture. J Mar Biol Ass UK 54: 825-855

30. Tilman D (1982) Resource competition and community structure. Princeton Monogr. Pop Biol 17: 296.

31. Forsberg C, Ryding SO (1980) Eutrophication parameters and trophic state indices in 30 Swedish waste-receiving lakes. Arch Hydrobiol 89: 189-207.

32. Canfield DE (1983) Prediction of chlorophyll a concentrations in Florida lakes: the importance of phosphorus and nitrogen. J Am Water Resour Assoc 19 $255-262$.

33. Hoyer MV, Frazer TK, Notestein SK, Canfield DE (2002) Nutrient, chlorophyll, and water clarity relationships in Florida's nearshore coastal waters with comparisons to freshwater lakes. Can J Fish Aquat Sci 59: 1024-1031.

34. Elser JJ, Marzolf ER, Goldman CR (1990) Phosphorus and nitrogen limitation 
Citation: Balali S, Hoseini SA, Ghorbani R, Kordi H (2013) Relationships between Nutrients and Chlorophyll a Concentration in the International Alma Gol Wetland, Iran. J Aquac Res Development 4: 173 doi:10.4172/2155-9546.1000173

Page 5 of 5

of phytoplankton growth in the freshwaters of North America: a review and critique of experimental enrichments. Can J Fish Aquat Sci 47: 1468-1477.

35. Downing JA (1997) Marine nitrogen: Phosphorus stoichiometry and the global $\mathrm{N}: \mathrm{P}$ cycle. Biogeochemistry 37: 237-252.

36. Redfield AC (1958) The biological control of chemical factors in the environment Am Sci 46: 205-221.
37. Ryther JH, Dunstan WM (1971) Nitrogen, phosphorus, and eutrophication in the coastal marine environment. Science 171: 1008-1013.

38. Jones JR, Bachmann RW (1976) Prediction of Phosphorus and Chlorophyl Levels in Lakes. J Water Pollut Control Fed 48: 2176-2182.

39. Carlson RE (1977) A Trophic State Index for lakes. Limnol and Oceanog 22 363-369. 